\title{
On Teaching of Foreign Language in Big Data Era
}

\author{
Shen Hongwei ${ }^{1, \mathrm{a}}$, Xu Daoping ${ }^{1, \mathrm{~b}}$, Zhao Weihong ${ }^{1, \mathrm{c}}$ \\ ${ }^{1}$ Qingdao Huanghai University \\ Qingdao, China \\ a290357329@qq.com, b1012225721@qq.com, c194430179@qq.com
}

\begin{abstract}
The arrival of the big data era has the vital impact on the traditional foreign language teaching. Environment of foreign language teaching, the roles of teacher and students, educational resources, evaluation and test have changed quietly. Conforming to this trend, it is put forward that foreign language teachers must promote the reform of teaching model and seek self-development by changing teaching concept, innovating teaching mode, improve their informational qualities, enhance the ability of integration of educational resources, reflect teaching and develop micro-research. It can be known that big data age inevitably requires teachers to become familiar with and master modern media technology, improve integration capabilities of using information technology and resources. However, teacher age, work area, computer hardware and software equipment, teacher time investment, teacher training and many other factors of imbalance. At the same time, schools and departments' managers should also keep pace with the times, and continue to improve the level of foreign language teaching management.
\end{abstract}

Keywords - big data era; foreign language learning; convert; strategy

\section{INTRODUCTION}

With the development of information technology, big data has been invading all aspects of our lives with the absolute strength, affecting the learners learning methods, innovating the educational philosophy of educators, changing people's way of thinking. At the same time it led to emergence and development of MOOCs and micro-lecture. Foreign language teaching in the era of large data cannot be outside of change, the foreign language classroom has undergone unprecedented changes. On the one hand, the contemporary (post-90) college students have shown dissatisfaction and soft resistance to the traditional English classroom. With the computer information and Internet technology is highly developed, large-scale data volume continues to emerge, human enter into the era of large data. On the other hand, foreign language teachers also feel that the contemporary college students are difficult to teach, difficult to get along with and difficult to deal with [1]. Thus classroom crisis was generated. In addition, the credits are reduced from 6 hours / week to 4 hours / week, and the credits are reduced from 16 to 12 or 8 . Under such circumstances how foreign language teachers and manager will change their concept, improve the quality of teaching, bring foreign language teaching reform into a new normal, which become an urgent issue to explore and solve.

\section{WHAT IS BIG DATA AGE}

\section{A. Meaning of big data age}

Big data is another subversive change after the emergence of the cloud computing, Internet of things. So what is "big data"? Can big data be understood as the "number" in life? In fact, "digital" is a narrow sense of the data, but the generalized data is a comprehensive description of the extraction, process, analysis and management of other information related to a number. For example, there are two students' scores are 90 points in a final exam, their English proficiency seems to be the same just from the figures of " 90 ". For the analysis the reasons of their academic performance, such as how is the two students' English foundation, learning motivation, respectively learning strategies, are there any differences among listening, speaking, reading, writing and translation? Is there any difference? What is the impact on learning teachers' teaching level, teaching methods, and the use of teaching materials, etc.

\section{B. Maintaining the Integrity of the Specifications}

We combine all the factors associated with this score, which constitutes a large data. The US Internet Data Center defines "big data" as a new technology architecture that captures value from high-volume data through high-speed capture, discovery / analysis. Its characteristics can be summarized as four letters $\mathrm{V}$, that is, greater volume, higher diversity (Variety), faster generation speed (Velocity) and by the previous three "V" combination of the first four factorsvalue [2-4]. From this we can see big data is completely different from simple "numbers", we can discover new knowledge and create new value by analyzing big data. Big data age will have a huge impact on personal lifestyle or education. Conforming to this trend, foreign language teachers should seize the momentum and meet the opportunities and challenges by changing the concept and adjusting thinking.

\section{The Change of Foreign LANGUAGe Teaching IN THE BIG DATA AGE}

The arrival of the big data era has the huge impact on the traditional foreign language teaching. Environment of foreign language teaching, the roles of teacher and students, educational resources, evaluation and test have changed quietly. 


\section{A. Changes in teaching and learning environment}

Big data age provides a new way of learning and unprecedented wealth of resources for foreign language teaching. Students can obtain the necessary learning resources through mobile phones, flat and other mobile terminals at anytime, anywhere. The boundaries between classroom and campus become blurred, ubiquitous learning will become a trend. Face-to-face learning and communication between teachers and students is decreasing, online interaction will become a new normal. Students from different countries and regions will meet and interact to form a temporary learning community by learning the same course at the same time.

The age of big data also led to the emergence and development of MOOCs and micro-lectures. Great changes have taken place in the teaching and learning environment. If learners are in the network environment, they will obtain the highest quality learning resources, which completely break the constraints of time and space, help to realize the education fair make equal access to education opportunities.

\section{B. Changes in the role of teachers and students}

Big data age, this has put information at the fingertips of students around the world than any other point in human history which is a tremendous advancement to help spread knowledge and understanding. Acquiring knowledge for students is no longer limited to the classroom and teaching materials, thus teachers are no longer the main source of knowledge. On the contrary, they can learn at anytime, anywhere according to their own needs and learning habits.

Students have more expectations for the relationship between teacher and student. They expect "teacher and student equality", rather than "teacher dignity", look forward to "teachers and students to build knowledge together" rather than "I tell, you listen." Teachers should follow this trend, transfer from knowledge and classroom managers to the organizers of the classroom and learning guider. English description of this change is more interesting: teachers from God into Guide, from Sage on the stage into Guide on the side, from Teacher into helper, councilor, facilitator and so on.

To be organizer, guider and questioner is not an easy thing for the foreign language teacher who are accustomed to the habit of "I master class, I tell you listen" Foreign language teachers not only need to be familiar with the teaching content, understanding the online courses which are available to learning resources, but also analyze the students' cognitive characteristics and learning style. In other words, the teacher's classroom preparation time is not diminished but increased.

The big data age teachers need to give the class back to the students, making the students to be the real subject of study. But at the same time, the students also need some specific requirements: First, have certain computer operation ability and information accomplishment. Second, be able to take the initiative to understand the relevant course information, learning objectives, classroom topics, after-school homework, examination time, etc. Then, be able to participate in the discussion, complete the assignments, the online test, the course examination, etc. In general, students who have a certain perseverance, strong self-discipline and self- management ability are able to make their own learning plans according to their own reality. On the contrary, students who are free and undisciplined are going to have a lot of trouble at school.

\section{Changes in educational resources}

Big data age, students have more expectations for learning materials, who prefer audio, video teaching resources to "paper knowledge". Smart phone, tablet PCs will become an effective aid for students to learn and access resources, which also changes their learning and reading habits. The results of the thirteenth national reading survey organized and implemented by the China Press and Publication Institute on April 19, 2016 show that digital reading (online reading, mobile reading, e-reading Reading, reading, Pad reading, etc.) was $64.0 \%$, up 5.9 percentage points from 2014 with the rapid development of digital media. Survey data show that in 2015 China's adult national average mobile phone reading time for the first time more than an hour. Among them, the per capita WeChat reading time is 22.63 minutes, compared to 14.11 minutes in 2014 increased by 8.52 minutes.

In addition, the rapid development of MOOCs and microlectures provides a large amount of curriculum resources for students to learn, MOOCs as massive online open courses, whose typical characteristics is large-scale and open. On the one hand, it can accommodate tens of thousands or even millions of students at the same time online learning. On the other hand, teachers are also required to have strong screening ability, so that the complex curriculum resources can be managed, can be processed, can be available to learning. As a new type of curriculum learning resources, the micro-course has the characteristics of learner-centered, the scene and the visualization, which is an important supplement and resource expansion for the traditional language classroom learning. If you compare the classroom to a meal, then the micro-class is one of the seasoning. The meal will add flavor and color by adding the proper seasoning.

\section{Changes in evaluation and test methods}

Big data provides people with a new way of looking at the world. Let the data speak. That is to say, data speaks louder than anything else [5,6]. This will also bring some changes to foreign language teaching evaluation and testing.

First of all, the traditional paper-and-pencil test will gradually decrease, replaced by machine test and online testing. Machine testing and online testing can not only ensure test feedback timely and effective, but also eliminate the subjective factors of teacher grading, which contributes to the test of fairness. Second, the development and large-scale use of intelligent test system can record the students' learning status, progress, effect and learning ability and keep the students' learning track intact. Teachers can view each student's learning path, state of study, and academic performance at any time. That provided the basis and realistic possibility for teachers to learn and further study of the students' cognitive characteristics and learning styles, to improve teaching methods, to offer different students individual teaching. It is beneficial for teachers to combine teaching practice and teaching research to transfer from the 
traditional and monotonous mode of summative assessment to formative evaluation. Make assessment involves the integration of summative evaluation and formative evaluation.

\section{THINKING AND STRATEGIES FOR FOREIGN LANGUAGE TEACHING}

Facing the opportunities and challenges brought by the era of large data, foreign language teachers should follow this trend, take effective measures to realize professional development. At the same time, schools and departments' managers should also keep pace with the times, and continue to improve the level of foreign language teaching management

\section{A. Change the teaching philosophy and innovating teaching mode}

In the era of big data and the context of compression foreign language class hours and credits, how to ensure the realization of teaching objectives. Foreign language teachers must change the concept of education. Anybody cannot master a foreign language by teaching, but by learning. Teaching is for the sake of no needing teaching [7]. The change of teachers' teaching idea is the premise of foreign language teaching reform, the traditional classroom teaching mode has lost the original important role in teaching in the era of large data. Modern teaching view that teaching is a process of teacher to trigger, maintain and promote students to learn. Thus, foreign language teachers should be acutely aware that all activities in the classroom should be student-centered. In the era of large data, the traditional classroom should transfer from face-to-face settings to the blended Learning mode in order to make the limited classroom time more effective. The micro-lectures and MOOCs can play a role in the flipped classroom and meet the needs of students personalized learning at the same time.

Personalized teaching is a trend, the application of microlectures, MOOCs and other video resources can effectively solve the individual problem since the famous education practice theorists Johann Amos Comenius in the traditional classroom teaching [8]. But in the application, teachers should have a correct understanding that not just shift micro-lectures, MOOCS and other high-quality online video resources into class. Take the micro-lecture for example, it is a teachingrelated video that teacher carry out the independence, integrity, short and effective teaching activities around a knowledge point, teaching links or a core issue in the teaching. Only in the case of students involved, can the micro-lecture be called lesson; whose essence is a new curriculum resource for teachers and students. The teachers who provide microlectures, MOOCs and other video resources should change their teaching philosophy, be aware of the curriculum to be faced to thousands or even hundreds of thousands learners with different regions, different levels, learning methods. So the content of the micro-lecture should be focused, the expression should be accurate, the design of media should meet the characteristics of studying on one's own and interactive learning.

Colleges and universities should make full use of information technology, create a diverse teaching and learning environment. Encourage teachers to build and use MOOCs, micro-lectures, transform and expand the teaching content by using of online quality education resources, implement blended learning based on the flipped class and online courses.

\section{B. Improve information literacy and enhancing the ability to integrate resources}

Big data age inevitably requires teachers to become familiar with and master modern media technology, improve integration capabilities of using information technology and resources. However, teacher age, work area, computer hardware and software equipment, teacher time investment, teacher training and many other factors of imbalance lead to the development of foreign language teachers and the level of application of information technology capacity is not uneven. To promote foreign language teachers to take the initiative to use a variety of multimedia resources, to carry out foreign language teaching practice, it is essential for foreign language teachers to take the following measures to improve their information literacy.

Today, a large number of comprehensive university institutions, gathered all kinds of professionals. Foreign language teachers should first establish the initiative to improve their awareness of information literacy, turn to colleagues or their students for help in the face of technical problems. First of all, to communicate with foreign language teachers to solve technical problems. As foreign language teachers, their teaching environment and professional background is roughly the same, thus peer explanation will not only help solve the problem, but also may bring some design inspiration. Second, you can ask your students for help, especially the students majoring in computer or animation art design and other professional, for they are often more prominent in the computer information technology applications. Then, you can go to information technology professional teachers or experts for help in the face of difficult technical problems, they can provide a more professional solutions.

In big data age, the multimedia courseware, micro-lecture production of various types of training and competition are emerging in an endless stream [9]. A lot of schools, whether men or women are required to participate in the process of production of micro-lectures. Competition provide an interactive platform for teachers from all directions to learn from. Many teachers say the competition is a selfimprovement process, they invest more time and energy in it, and thus their level of production have improved greatly.

Computer and Internet technology makes it possible for the network training, and network training specific time, portable, low cost, without long-distance rush, breaking the time and space constraints. It is conducive for teachers to improve learning. But the disadvantage is that teachers lacking a sense of belonging in the training, and some teachers are difficult to adapt to the habit of learning the Internet, who are lacking of interaction between teachers, thus the learning effect isn't productive. Therefore, schools should also carry out school-based training, which enables teachers to have the opportunity to participate in training. In addition, select the 
backbone teachers regularly to participate in the training provided by the government, publishers and societies [10]. It is also effective to improve the teaching methods.

\section{Change the concept of teaching management, improve management efficiency}

Big data age brings a lot of changes to foreign language teaching, schools and departments should also keep pace with the times, changing the concept of teaching management, adopting three management mechanism: school, faculty, teaching and research section, constantly improving the level of foreign language teaching management and management efficacy. Establish and improve the information-based teaching management system, formulate online hours/credits and online learning assessment management system, build a good network teaching management platform. Encourage foreign language teachers to establish the concept, to enhance their professional level and information literacy, and promote the innovation of teaching mode, take the initiative to meet the requirements of foreign language teaching under information environment, Bring foreign languages teaching reform into the new normal.

\section{CONCLUSION}

With the study of "On Teaching of Foreign Language in Big Data Era", it can be known that the big data age teachers need to give the class back to the students, making the students to be the real subject of study. As a result, the change of teacher's teaching concept is the premise of foreign language teaching reform. The traditional classroom teaching model has lost its original teaching role in the era of big data. The modern teaching view holds that teaching is the process of triggering, maintaining and promoting students' learning. Therefore, foreign language teachers should be keenly aware that all activities in the classroom should be centered on students.

\section{REFERENCES}

[1] H.W. Shen, H.X. Jiang. "Study on autonomous development of college English teachers in big data era". Journal of Changchun University,2015,pp.96-99.

[2] Y.N. Zhang, Zh.J. Zhao. "Reflections on inspiration for education from thinking mode in big data age".Institute of curriculum and instruction,2013,pp.1-5.

[3] D.M. Mei. "A big-data approach to the study of language ecology". Research center for foreign language strategies, 2014,pp.3-10.

[4] Allen, I. Elaine|Seaman, Jeff. "Going the Distance". Online Education in the United States, 2011, pp.44-48.

[5] Project N H, Gong Z W, Di W U, et al. "The NMC Horizon Report: 2014 Higher Education Edition". Journal of Guangzhou Open University, 2014,pp.12-22.

[6] Wang X F, Davies M, Liu G H. "A Good Platform for English Teachers and Learners:the Corpus of Contemporary American English(COCA)". Computer-Assisted Foreign Language Education in China, 2008, pp.215-218.

[7] Medgyes P. Nonnative. "Speaker English Teachers: Research, Pedagogy, and Professional Growth”. ELT Journal, 2011, pp.210-212.

[8] Negretti R, Kuteeva M. "Fostering metacognitive genre awareness in L2 academic reading and writing: A case study of pre-service English teachers". Journal of Second Language Writing, 2011, pp.95-110.

[9] Noomura S. "English-Teaching Problems in Thailand and Thai Teachers' Professional Development Needs". English Language Teaching, 2013, pp.12-18.

[10] Shin S K. "It Cannot Be Done Alone": The Socialization of Novice English Teachers in South Korea". Tesol Quarterly, 2012, pp.542-567. 